\title{
モルタル熱電対法によるセメント硬化体の凝結時間の評価方法の提案 \\ EVALUATION METHOD FOR TIME OF SETTING OF MORTAR MIXTURES BY THE MORTAR THERMOCOUPLE METHOD
}

\author{
小山明男*1, 山川勉*2, 竹 村 太一*3, 高見澤 直寿*4 \\ 小宮岳枝*5, 捧 剛 明*6, 菊池雅史*7 \\ Akio KOYAMA, Tsutomu YAMAKAWA, Taichi TAKEMURA, Naohisa TAKAMIZAWA, \\ Takeshi KOMIYA, Yosiaki SASAGE and Masafumi KIKUCHI
}

\begin{abstract}
In recent years, the control of setting time of concrete has become significant due to the development of various kinds of concrete. In general, JIS 6204 specifies the test method of setting time of mortar mixtures by penetration resistance. However, since measuring the penetration resistance in the case of long setting time requires considerably a great deal of complicated work, the simple way to predict the setting time could be advantageous in quality control at the concrete industry. This paper proposes an evaluation method of setting time of mortar mixtures by mortar thermocouple method comparing the test results by a mortar thermocouple method with penetration resistance using the sample mortars containing the diverse kinds of admixtures and three different aggregates. A mortar thermocouple method could evaluate the setting time by automatically measuring a thermal hysteresis
\end{abstract}

Keywords : Setting Time, Mortar Thermocouple Method, penetration resistance, admixture

凝結時間，モル夕ル熱電対法，貫入抵抗值，混和材料

1.はじめに

近年, 建物の高層化や生産性向上などの要求から, 高強度コンクリ 一ト,高流動コンクリートなど多様なコンクリートが開発されている。 これらのコンクリートの原材料として, 軽量骨材, シリカフュームや 高炉スラグ微粉末などの混和材, 凝結遅延剤および凝結促進凨, ある いは押出成形板のバインダーや分離低減剤など数多くの種類の化学 混和剤などが使用されている。また，環境への配慮や資源の有効利用 などの観点から，産業副産物を原料とした混和材，人工骨材などの利 用拡大が予想され，コンクリート材料の種類は多様化している。この ような背景より,さまざまな混和材料を使用している種々のコンクリ 一トの凝結特性を把握することは, 作業性の向上, 工場生産品の製造 ラインの急停止防止への対応など良好な生産性を確保する上で非常 に重要なことである。

凝結試験は JIS A 6204 (附属書 1) による試験方法が規定されてい るが, 凝結時間が長い場合など労力が非常にかかり, 人為的ミスの可 能性なども起こりえる。既往研究などにおいて JIS A 6204 (附属書 1） に代わる疑結試験方法としてカロリーメータ一法や超音波波動伝達 関数による評価 'が行われている。また, 本研究と同様の方法で温度

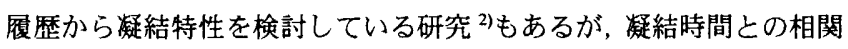
関係について十分に明らかにされていない。
そこで本研究は, 簡易な試験によりセメント硬化体の凝結特性を明 らかにすることを目的とし，JIS A 6204 （附属書 1）の凝結試験に代 わる新たな方法としてモルタル熱電対法を提案するため, モルタル熱 電対法による温度履歷試験結果と JIS A 6204 (附属書 1) による凝結 試験結果を比較し，モルタル熱電対法による凝結時間の予測精度につ いて検討するものである。なお, 本試験方法は多少の誤差は生じるも のの, パソコンによる自動計測のみにより，多大な労力をかけずに凝 結時間を予測できることが特徴である。

\section{2. 実験概要}

\section{1 使用材料}

本実験はJIS A 6204 に準じ，細骨材に硅砂（以下，k）を用いたモ ルタルによる実験を中心に行ったが, 骨材特性が疑結時間に及ぼす影 響を確認し，より試験方法の汎用性を高めるために，吸水率の高い人 工軽量骨材として, 膨張頁岩系人工軽量紐骨材（以下， m) および廃 カラス系人工超軽量細骨材（以下，g）を用いた。表 1 に使用材料お よび骨材物性を示す。

\section{2 使用材料の物性および調合概略}

表 2 に調合概略を示す。 $\mathrm{k}$ は結合材と細骨材の質量比を $1: 1$ として 実験を行った。水結合材比（以下, W/B）を 30, 40,50\%の 3 水準
*1 明治大学理工学部建築学科 講師. 工博

*2 信越化学工業侏合成技術研究所工博

*3 明治大学理工学研究科建築学専攻 博士前期課程

*4 明治大学理工学部建築学科

*5 株デイ・シイ

*6 信越化学工業(陎合成技術研究所

*7 明治大学理工学部建築学科 教授・工博
Assistant Prof., Dept. of Architecture, Science and Technology, Meiji Univ., Dr. Eng.

Speciality Chemicals Research Center, Shin-Etsu Chemical Co., Ltd., Dr. Eng. Graduate Student, Graduate School of Architecture, Science \& Technology, Meiji Univ.

School of Architecture, Science \& Technology, Meiji Univ.

DC Co., Ltd.

Speciality Chemicals Research Center, Shin-Etsu Chemical Co., Ltd

Prof., Dept. of Architecture, Science and Technology, Meiji Univ., Dr. Eng. 
減水剂は添加率 $0,0.2,0.35,0.5 \%$ の 水準, 高性能減水剂は SP が 添加率 $0,0.5,1.0 \%$ の 3 水準， NL が添加率 0, 0.5，1.0，2.0, 3.0\% の 5 水準，増粘剤（以下，CE）は成分の異なる 6 種類（A1〜A6）で それぞれ $0,0.2 ， 0.4 ， 0.6 ， 0.8 ， 1.0 ， 2.0 \%$ の 水準の添加率, 凝結 遅延剂は成分の異なる 3 種類でそれぞれ $0,0.05 ， 0.1 ， 0.15 ， 0.2 \% の$ 5 水淮の添加率, 凝結促進剂法成分の異なる 2 種類でそれぞれ $0,0.5$, 1.0, 3.0\%の 4 水準の添加率, 高炉スラグ微紛末（以下, BFS）は混 入率 $0,30,50,70 \%$ の 4 水準, フライアッシュ（以下，FA） は混入 率 $0 ， 10 ， 20 ， 30 \%$ の 水準であり，91 種類の試料を用意した。 $\mathrm{m}$, $\mathrm{g}$ では $\mathrm{k}$ と同一の単位水量としたため, $\mathrm{m}$ では結合材と細骨材の質量 比を $1: 0.6, \mathrm{~g}$ では $1: 0.3$ とした。また, W/B を 40,50\%の 2 水準, 減水剤は添加率 $0,0.35 \%$ の 2 水準, 高性能減水郕（NL）は添加率 0 , $1 \%$ \% 水準, $\mathrm{CE}$ は成分の異なる 2 種類 (A4， A5) それぞれ 0, 0.2, $1.0 \%$ の 3 水準の添加率, FA は混入率 0, 20\%の 2 水準, BFS は混入 率 $0,50 \%$ の 2 水準の軽量骨材を用いた場合であり 22 種類で骨材 $\mathrm{k}$ を用いた場合と合わせて計 113 種類の試料を用意した。

\section{3 練り混ぜ方法}

練り混ぜはモルタルミキサーで行った。はじめにセメントと混和材 料で 1 分間練り混ぜ，その後，水书よび混和郕を投入し 1 分 30 秒紗 り混ぜ，最後に 1 分 30 秒練り混ぜ，合計 4 分間とした。

\section{4 試験項目および試験方法}

表 3 に試験項目および式験方法を示す。

\section{5 モルタル熱電対法の概要}

熱電対法とは, 各試料についての水和熱による発熱温度と経過時間 の関係を熱電対により測定する方法である。本方法では，試料モル夕 ルの温度が熱電対の先端をステンレスで䛃った熱電対センサーによ って自動的に計測され最大温度到達以降 $24.0^{\circ} \mathrm{C}$ 以下になったところ で計測を終了とした。そして，モルタル熱 電対のグラフ（図 1) で得られた特性值（最 大温度到達時間と温度上昇開始時間) と貫 入抵抗值から求まる JIS A 6204 (付属書 1) の凝結試験のグラフ（図2）で得られた凝

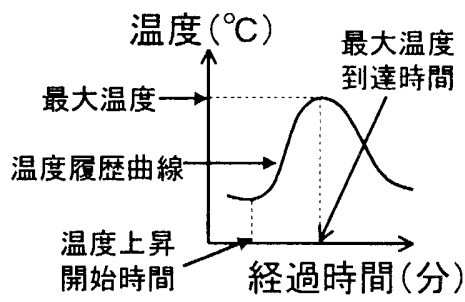

図 1 モルタル熱電対法

\section{貫入抵抗値}

$\left(\mathrm{N} / \mathrm{mm}^{2}\right)$

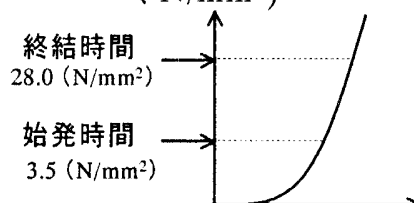

経過時間(分)

図 2 貫入抵抗值法のグラフ（右）
結時間（始発時間と凝結時間）について比較検討を行つた。モルタル の温度が上昇し始めた時間を温度上昇開始時間と定義した。

表１使用材料および骨材特性

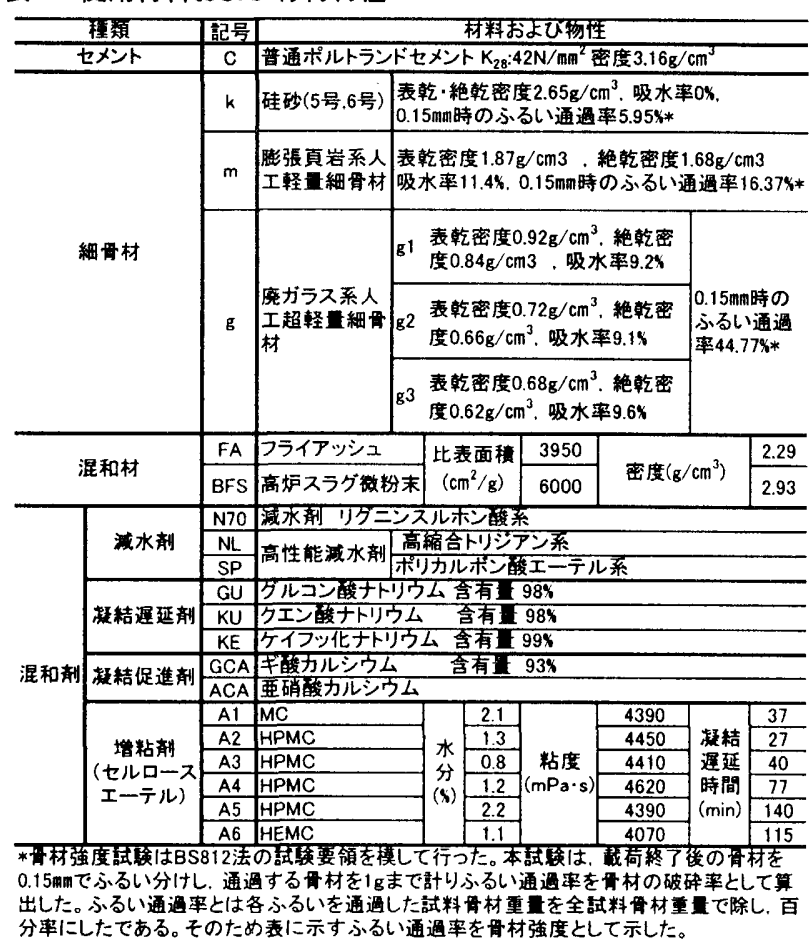

表 3 試験項目および試験方法

\begin{tabular}{|c|c|}
\hline 試㡎項目 & 詿験方法 \\
\hline$\frac{\text { フレッシュ性状 }}{\text { プ結特性 }}$ & 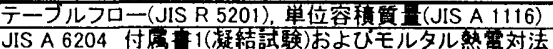 \\
\hline 強度特性 & 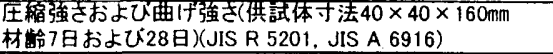 \\
\hline
\end{tabular}

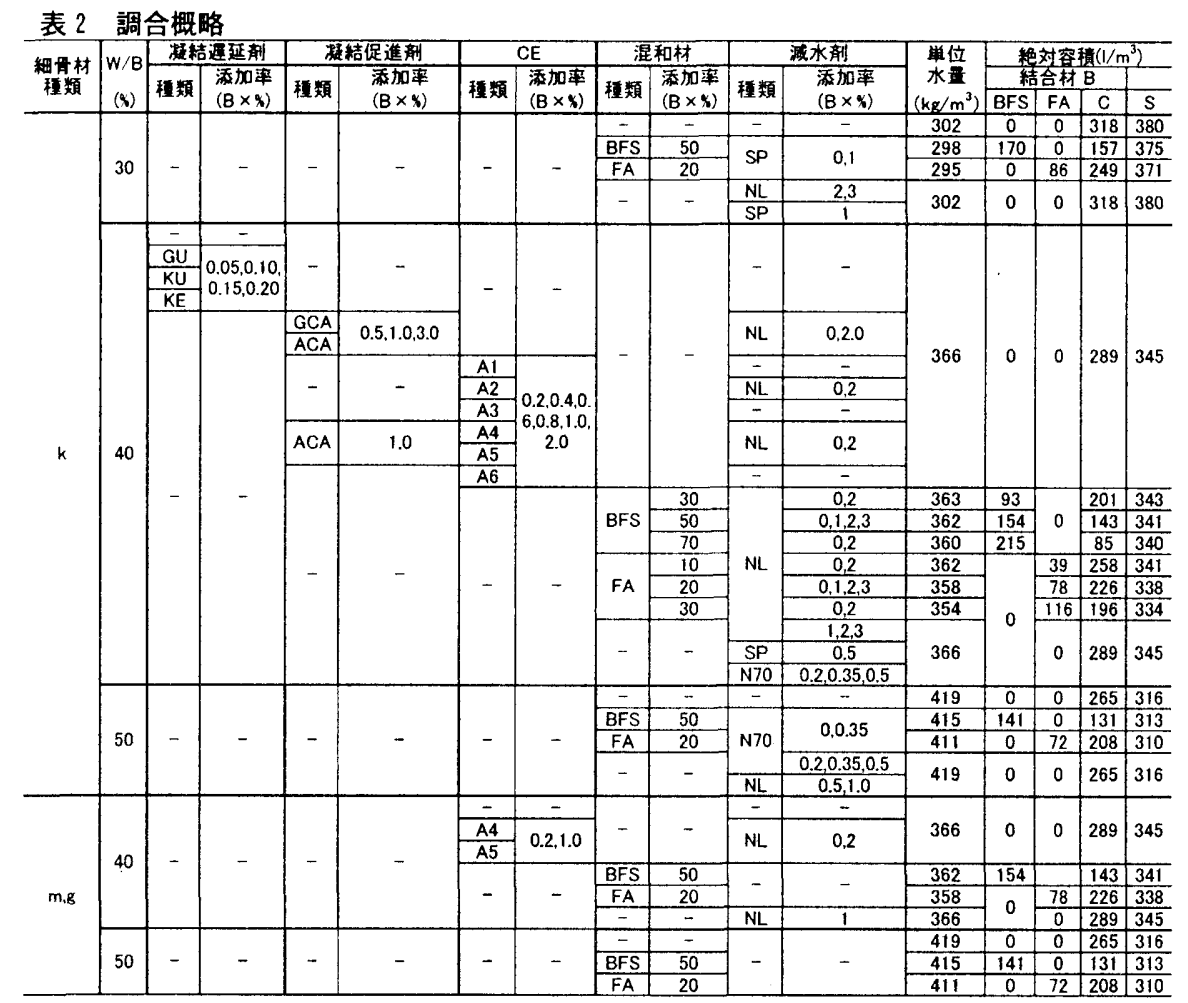


熱電対センサー(Pt-Rh熱電対 $\cdots$

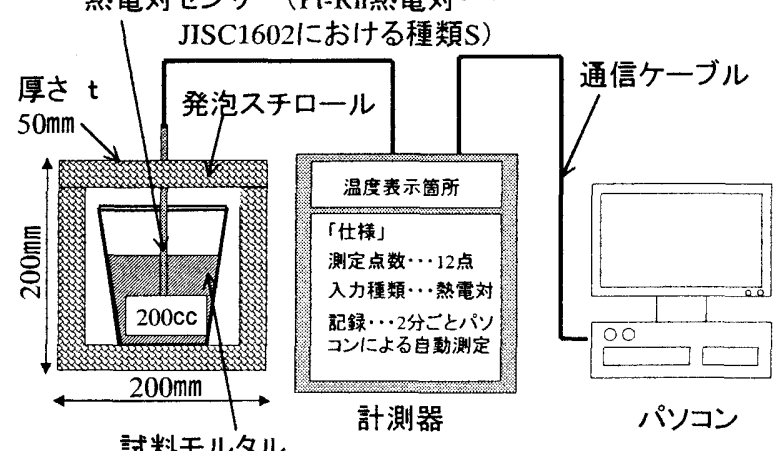

図 3 モルタル熱電対法の概要図

試料モルタルはプラスチックの容器に $200 \mathrm{cc}$ 入れ, 発泡スチロー ル容器 $(200 \times 200 \times 200 \mathrm{~mm}$, 直径 $120 \mathrm{~mm}$, 厚さ : $50 \mathrm{~mm})$ で樈った (写 真 1)。経過時間は, セメントに水を投入した時刻を水和開始 0 分と したなお，1 日で行える試料数に限りがあるため，毎回基準として W/B:40\%の混和材料無混入の試料を用意しこの試料の值との凝結時 間の差を用いて検討した。試呀室内の環境について凝結試験は JIS A

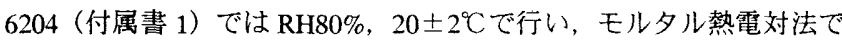
は試料モルタルが断熱容器で密封されているため RH60\%, $20 \pm 2{ }^{\circ} \mathrm{C}$ とした。また，図3にモルタル熱電対法の概要図を示す。

\section{3. 実験結果および検討}

\section{1 フレッシュ性状および强度試験}

図 4 に CE（A4）および凝結这延剂，凝結促進剂（以下，凝結時間 調整剂）を添加した試料の 15 打フロー値の一例を示す。CEと凝結遅 延剤は添加率の増加により，15 打フロ一値は低下した。一方，凝結 促進剤を用いた試料ではばらつきが認められた。

図 5 に CE（A4）および疑結時間調整剤の添加率と圧縮強さの関俰 を示す。特に CE は添加率 1.0\%で圧縮強さが約 37\%低下した。これ は， $\mathrm{CE}$ の特性により空気が巻き込まれるためと考えられる。また, 凝結遅延剂は $0.15 \%$ ，凝結促進剤は $1.0 \%$ で圧縮強さが頭打ちになる ことが分かった。高性能滅水剤を併用した場合，CE は NL添加率に よる影響は認められなかったが, 凝結促進剂では圧縮強さが低下する 結果となった。

図には示さないが，骨材種類による影響として， $\mathrm{k}$ に比べて $\mathrm{m}, \mathrm{g}$ はフロー值が大きくなった。

以上のように, 本実験はフローや圧縮強さを同一にした試料で疑結 特性を検討したのではなく，あくまで，調合要因を統一的にした試料 により比較検討したものである。

\section{2 凝結試験（JIS A 6204 付属書 1 における貫入試験）}

ここでいう凝結遅延・促進時間は，比較対象とした同一の W/B に おける混和材料無添加と比べて逮延した時間として定義している。

図 6 に CE（A2，A4）および凝結時間調整剂の添加率と始発逮延・ 促進時間の関係の一例を示す。これより，いずれの混和剤も種類によ らず添加率の增加にともない，始発革延・促進時間が長くなることが 認められた。また, 同一の添加率でも種類によって始発遅延時間が大 きく異なる結果となった。
図 7 に混和材に高性能減水剂を併用した場合の凝結逯延時間の一 例を示す。始発逮延時間において混和材は単独で使用した場合, 始発 遅延時間は最大で約 30 分であった。しかし, 高性能減水剤を併用す ることで始発遅延時間が長くなることが認められた。なお，終結遅延 時間においても同様の傾向を示した。四には示さないが CE（A2）に 高性能減水剂 NLを $2 \%$ 併用した場合, 始発・終結時間ともに約 200

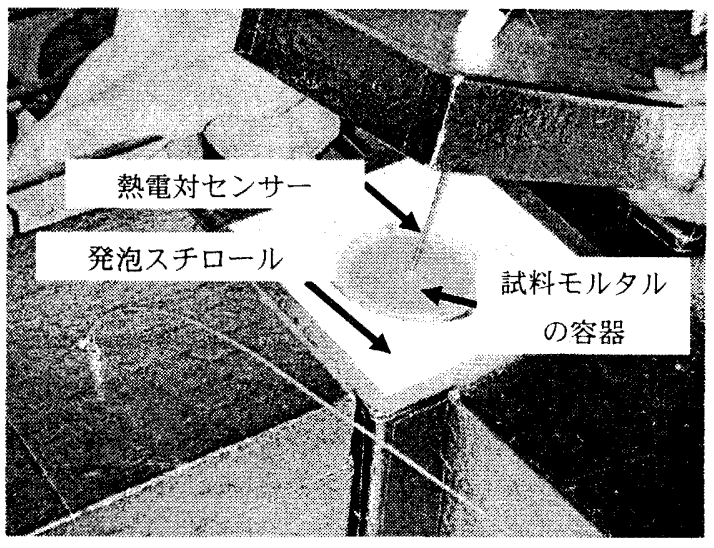

写真 1 モルタル熱電対法の詳細

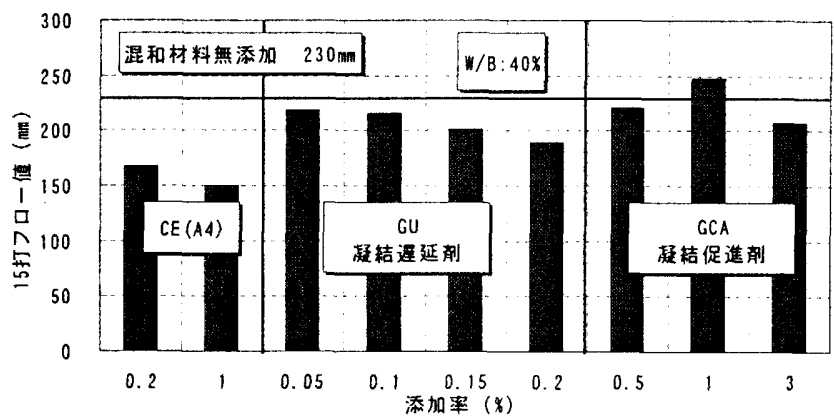

図 4 添加率と 15 打フロー値の関係（CE，凝結時間調整郕）

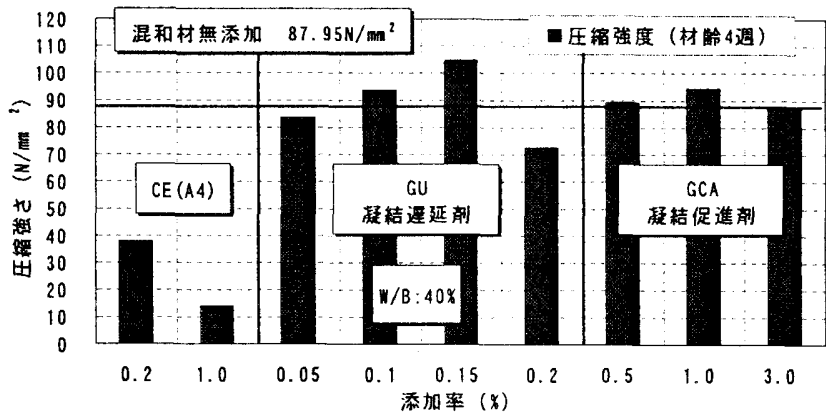

図 5 添加率と圧縮強さの関係（CE，凝結時間調整䬉)

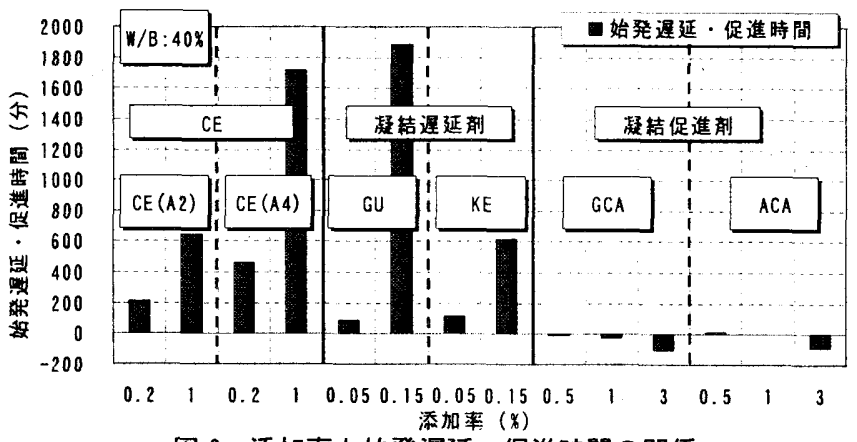

図 6 添加率と始発遅延・促進時間の関係 (CE，凝結時間調整剤) 
分長く遅延することが確認された。

図 8 に W/B 別の各骨材の凝結遅延時間の関倸の一例を示す。この 図の凝結遅延時間は，同一の骨材 $\mathrm{k}$ を用いたモルタルの始発・終結時 間との差である。これより，骨材 $\mathrm{m} ， \mathrm{~g}$ は骨材 $\mathrm{k}$ と比較し始発・終結 時間が遅延する傾向を示した。また，混和材料を添加・混入した場合 は, $\mathrm{k}$ と同様に添加・混入率の增加により始発・終結時間が遅延する

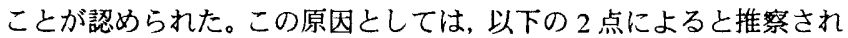
るが, 軽量骨材 $(\mathrm{m}, \mathrm{g})$ を比較すると $\mathrm{g}$ の方が $\mathrm{m}$ に比べて吸水率が 小さいのに対して凝結時間は長いことから(1)の原因によるものでは なく，骨材強度の影響である(2)の原因によるものと考えられる。 (1)軽量骨材に水分が多く含まれるため比熱が高くなることで, 練り上 がり温度が低下し，セメントの水和反応速度が若干逮れた。

(2)本試験方法による凝結試験は, 貫入抵抗值によって評価されるため, セメントの水和反応速度が同じでもより, 強度の小さい（表 2 に示し た $0.15 \mathrm{~mm}$ 時のふるい通過率が大きい）骨材を用いた試料モル夕ルで は，凝結時間が逯延されたことになる。

また, 図には示さないが, いずれの混和材料においても添加率の増 加にともない凝結時間は遅延することが羿められた。

\section{3 温度履歴（モルタル熱電対法試験）}

図 9 に CE（A2，A4）㧍よび疑結時間調整郕添加率と最大温度㧍よ び最大温度到達時間の関倸の一例を示す。これより， $\mathrm{CE}$, 凝結逮延 剂を用いた試料は種類によらず, 添加率が增加するほど最大温度は低 くなり, 最大温度到達時間は幄くなっている。一方, 凝結促進剤を用 いた試料では，CE，凝結逮延剤と逆の傾向を示した。

図 10 に混和材（郕）料の添加・混入率と最大温度および最大温度 到達時間の関係の一例を示す。こちらも，CE や結还延霅と同様の 傾向を示している。特に, BFS では混入率の增加により最大温度が低 下する傾向が顕著に認められた。

図 11 に NL 添加率と最大温度および最大温度到達時間の関係の一 例を示す。これより, 高性能減水䬉 NLと混和材を併用した影響は最 大温度より最大温度到達時間で顕著に認められ，NL 添加率の増加に ともない最大温度到達時間は遅くなった。図には示さないが, その他 の混和材料においても同様の結果となった。

図 12 に骨材種類別の最大温度および最大温度到達時間の関係を示 す。これより，骨材による影響は，最大温度に及ぼす影響が小さく， W/B が大きいほど最大温度到達時間に及ぼす影響は顕著である。

\section{4 凝結試験とモルタル熱電対法の相関関係}

本検討は各試料の凝結試験とモル夕ル熱電対法の相関関係を検討 したものであり，各試料の凝結性状について検討したのではない。

図 13 に全試料における最大温度と凝結時間(始発時間および終結 時間)の関係を示す。これより最大温度が大きくなると疑結時間は早 くなる傾向がある。ただし, いずれの骨材においても最大温度が低 い BFSやFAを用いた場合に多少ばらつきが認められた。よって，混 和材を用いた場合の最大温度による凝結時間の推定は難しいと考え られる。

図 14 および図 15 に CE，凝結遅延剂および疑結促進剤を添加した 試料における温度上昇開始時間および最大温度到達時間と始発時間 の関倸を示す。これらより，骨材による影響も認められず，どちらの 特性值においても始発時間の推定は可能であると考えられる。
図16および図17に混和剂を添加した試料の最大温度到達時間およ び温度上昇開始時間と始発時間の関倸を示す。温度上昇開始時間では ばらつきがあったものの, 最大温度到達時間で始発時間の推定は可能 であると考えられる。

図18および図19に混和材を混入した試料の最大温度到達時間およ び温度上昇開始時間と始発時間の関係を示す。これより，どちらの特 性值においても BFS では高い相関性が得られなかった。一方，FAで は始発時間は最大温度到達時間で推定が可能と考えられる。

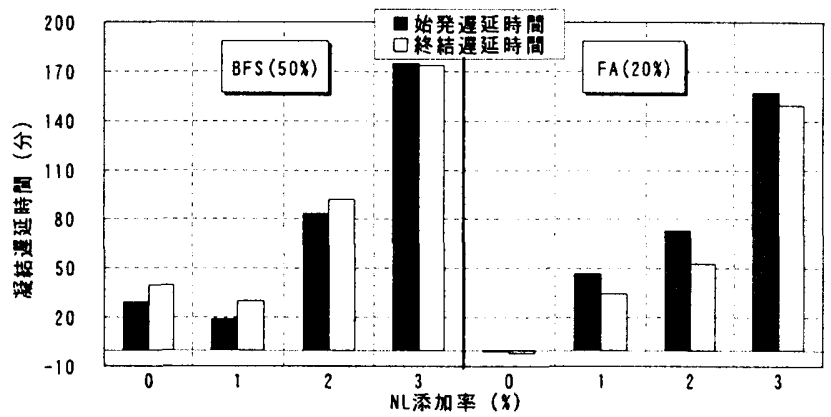

图 7 NL 添加率と凝結遅延時間の関倸

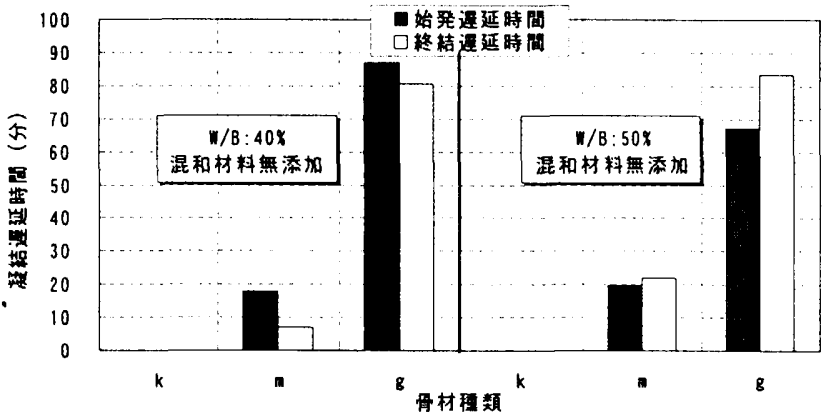

図 8 骨材種類と凝結遅延時間の関倸

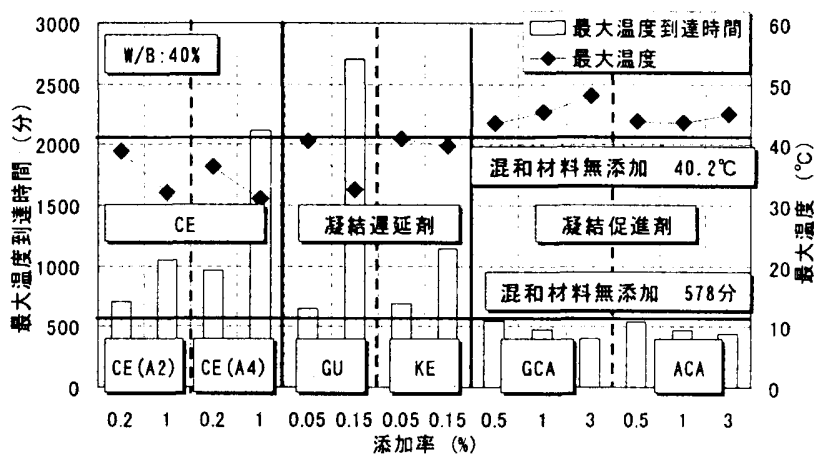

図 9 添加率と最大温度到達時間および最大温度の関係 (CE，凝結時間調整珮)

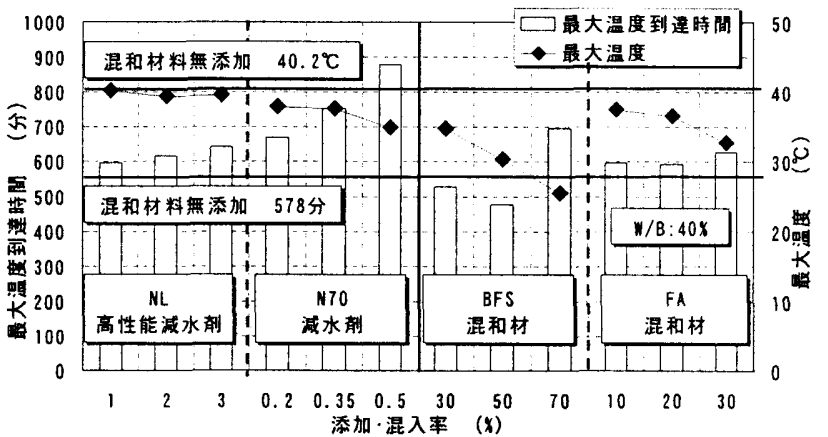

図 10 添加・混入率と最大温度到達時間および最大温度の関係 (減水剂, 混和材) 
このようにBFS とFAとで若干異なる傾向を示したことから, 今後, 水和反応のメカ二ズムと温度履歴との関係を検討する必要がある。

また, 図には示さないが, 高性能減水剤を併用した場合は混和材の 相関性が高くなる結果となり, 終結時間はいずれの混和材料でも始発 時間と同様の傾向が得られた。

表 4 に本実験の範囲における凝結試験とモルタル熱電対法の相関

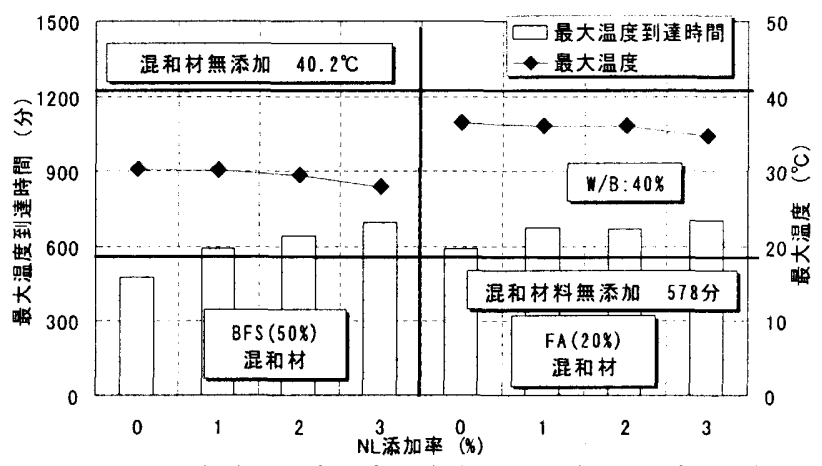

図 11 NL 添加率と最大温度到達時間および最大温度の関係 （混和材と高性能减水刘の併用）

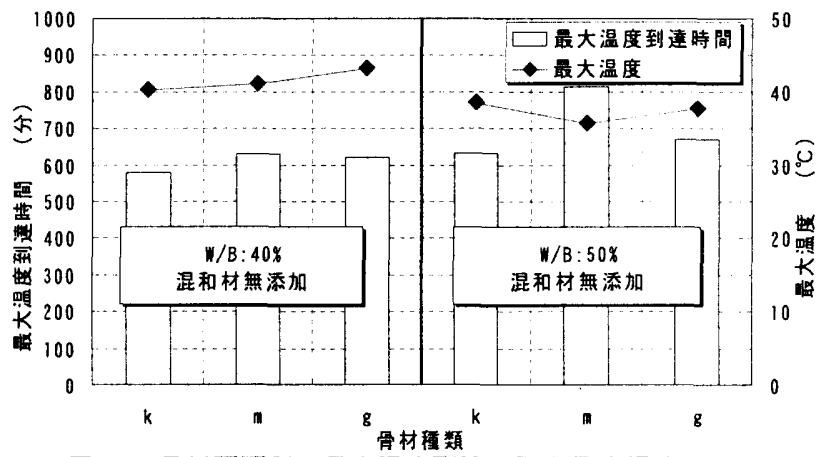

図 12 骨材種類別の最大温度到達時間と最大温度の関係

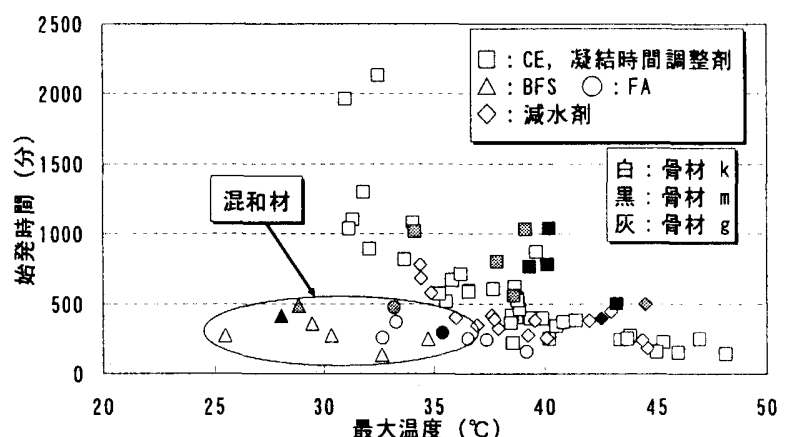

図 13 最大温度と始発時間の関係

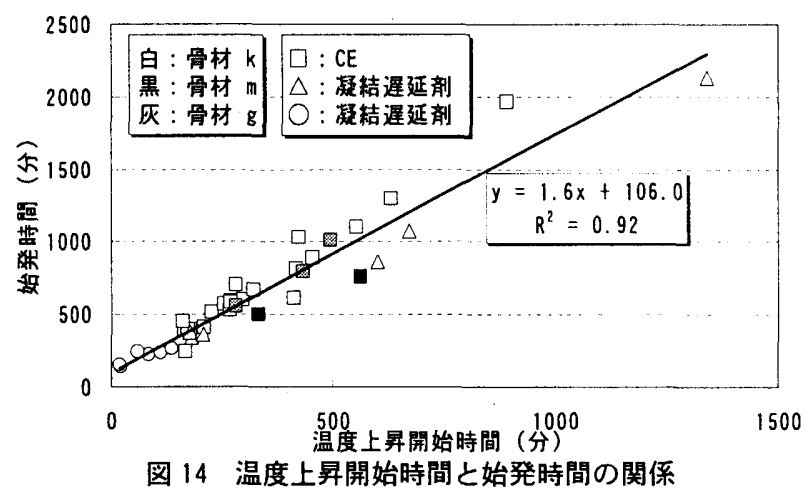

(CE，凝結時間調整剤)
関係を示す。本実験の範囲では, モルタル熱電対法試験を行い最大温 度到達および温度上昇開始時間を求め, 以下の推定式を用いることで, セメント硬化体の始発および終結時間を推定できると考えられる。

推定式 : $s=\mathrm{a} t+\mathrm{b}$

ここで $\quad s:$ 凝結時間（始発または終結）,

$t:$ 温度上昇開始時間または, 最大温度到達時間 $a, b$ 実験定数

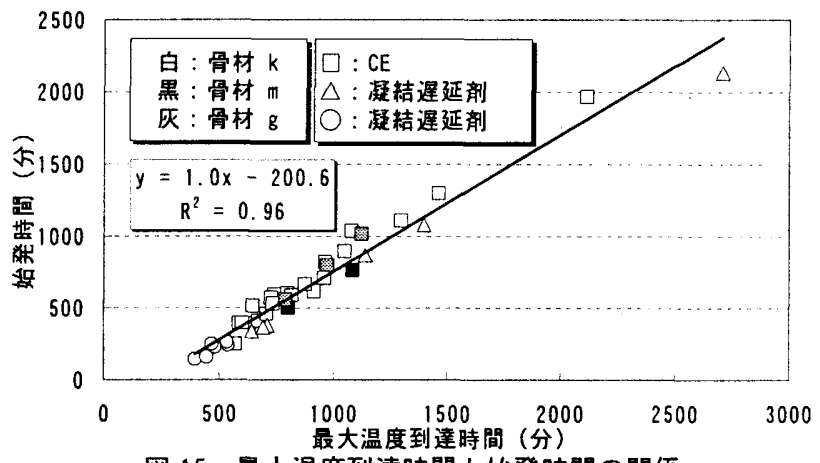

図 15 最大温度到達時間と始発時間の関係 (CE，凝結時間調整鼡)

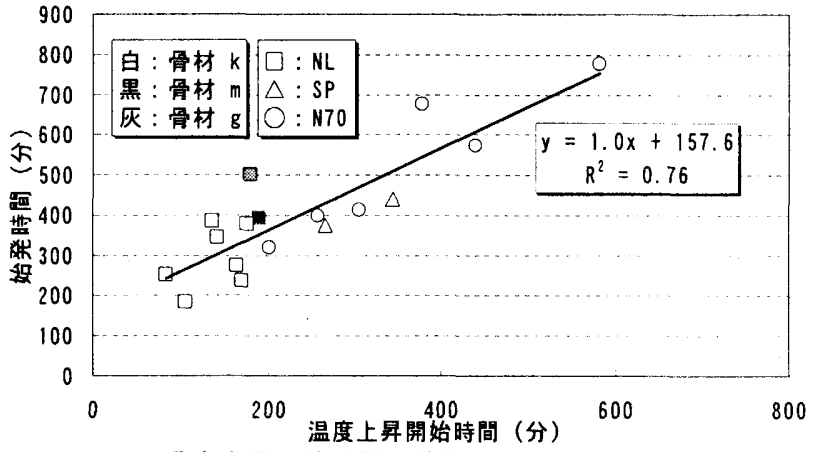

図 16 温度上昇開始時間と始発時間の関係（減水剂）

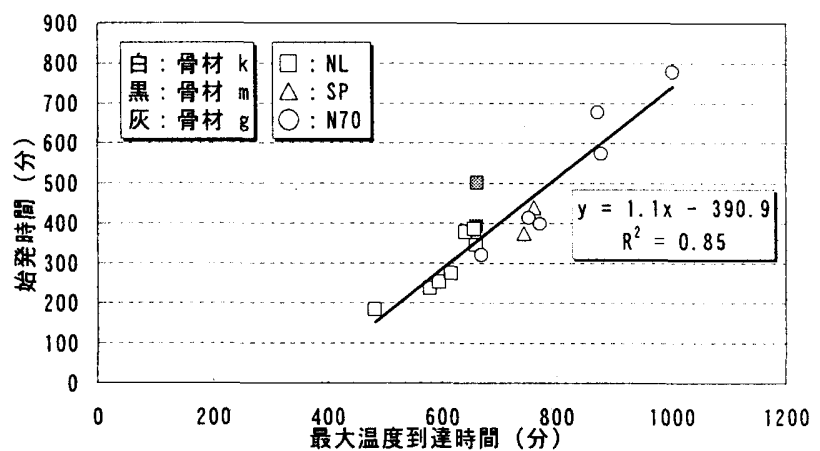

図 17 最大温度到達時間と始発時間の関係（減水剂）

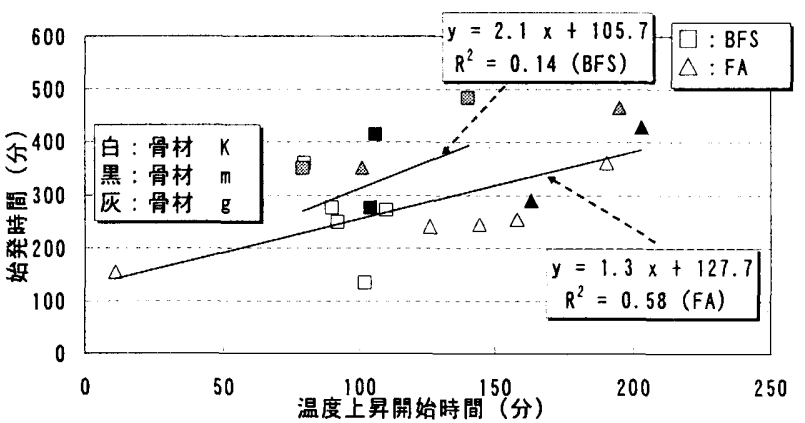

図 18 温度上昇開始時間と始発時間の関係（混和材） 
相関の強さに関しては一般に以下のような表現が用いられているが。

$$
\begin{array}{ll}
0.0<|R|<0.2 & \text { ほとんど相関なし } \\
0.2 \leq|R|<0.4 & \text { 弱い相関あり } \\
0.4 \leq|R|<0.7 & \text { 比較的強い相関あり } \\
0.7 \leq|R|<1.0 & \text { 強い相関あり }
\end{array}
$$

そこで,これを用いて各相関係数が 0.7 以上を@， 0.4 以上 0.7 末満

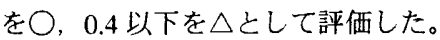

これより，モルタル熱電対法による凝結時間の評価は BFS を用い た場合以外で良好な相関関係が得られた。

表 5 に表 4 の赛験定数を用いて（1）式から 推定した推定時間亡実際の始発時間の平均値

（実測時間／推定時間）および変動係数を示 す。また, 図 20 に全試料の温度上昇開始時間 における（1）式の推定時間と JIS A 6204（付 属書 1）における始発時間の比較, 図 21 に最 大温度到達時間における（1）式の推定時間と JIS A 6204（付属書 1）における始発時間の 比較を示す。

表 5 より，最大温度到達時間および温度上 昇開始時間のいずれにおいても変動保数は BFS を用いた場合以外は，ほほ $20 \%$ 以内であ った。なお，終結時間においても同様の傾向が 認められた。図 20〜図21より全試料でみると 実測時間 /推定時間の平均値は 1.0 に近く, 変 動倸数は 25\%以内であった。実験定数について は, さらに広範囲な実験により精度は向上する が，モルタル熱電対法より得られた特性值と表 4 の実験定数を用いた式により簡易に凝結時間 の推定が可能であると考えられる。

\section{4. まとめ}

凝結性状の把握のための新たな試験方法としてモルタル熱電対法 を提案した。本研究では，混和材料の種類やその水準など，非常に 広範囲の試験を実施し，その結果から JIS A 6204 (付属書 1) の凝 結試験方法に対して高い相関性が得られた。よって，モルタル熱電 対法は簡易的な凝結試験方法として十分に実用性を有するといえる。 ただし，本試験方法は，温度履歴による評価をもとにしているため 高炬スラグ微粉末を使用した場合の評価が難しい点など, 適用範围に 若干の課題も残る。今後は, 水和反応のメカニズムなどを含めて論理 的な轰付けを行い,さらに精度の高いものを目指し検討する予定であ る。

\section{「謝辞」}

本研究に際し，(株）エヌエヌビ一，(株）デイ・シイ, クリスタルク レイ(株), 日本メサライト工業（株）, 電源開発（株）ならびに本研 究室平成 $13 ， 14 ， 15$ 年度卒業生に協力頂きました。ここに嬮く敬意 を表します。

表 4 全試料における相関表

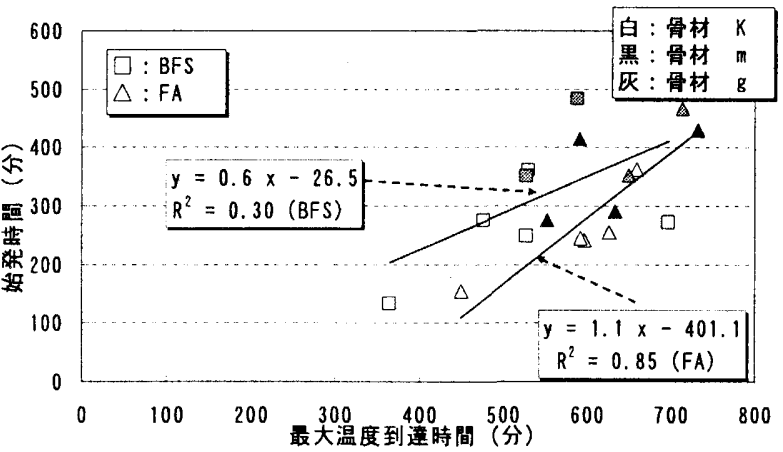

\begin{tabular}{|c|c|c|c|c|c|c|c|c|}
\hline & $\begin{array}{c}\text { (1) 混和刺 } \\
(n=17)\end{array}$ & (2) $B F S(n=9)$ & (3)FA $(n=9)$ & $\begin{array}{c}\text { (4) 增粘绪 } \\
(n=26)\end{array}$ & 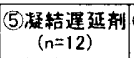 & $\begin{array}{c}\text { (6) 提結促進剒 } \\
(n=6)\end{array}$ & 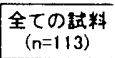 \\
\hline & & 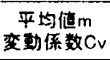 & 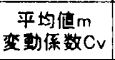 & $\begin{array}{c}\text { 平均偪 } \\
\text { 変動係数 } \mathrm{Cv}\end{array}$ & $\begin{array}{c}\text { 平的梴m } \\
\text { 変動係数 } \mathrm{Cv}\end{array}$ & $\begin{array}{c}\text { 平均健m } \\
\text { 変動保数 } \mathrm{Cr}\end{array}$ & 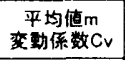 & $\begin{array}{c}\text { 平均値m } \\
\text { 变動係数 } \mathrm{Cv}\end{array}$ \\
\hline \multirow{2}{*}{$\begin{array}{l}\text { 量大温度 } \\
\text { 到遠時间 }\end{array}$} & \multirow{2}{*}{\begin{tabular}{|l|} 
\\
始吐 \\
時间 \\
\end{tabular}} & $\mathrm{m}: 1.0$ & $\mathrm{~m}: 1.1$ & $\mathrm{~m}: 0.9$ & $\mathrm{~m}: 1.0$ & $\mathrm{~m}: 1.0$ & $\mathrm{~m}: 1.0$ & $\mathrm{~m}: 1.0$ \\
\hline & & $C_{v: 15.1}$ & Cv: 25.3 & $C_{v: 18.9}$ & $C_{v}: 11.0$ & Cv:7.6 & Cv: 13.0 & $C_{v: 24.5}$ \\
\hline \multirow{2}{*}{$\begin{array}{l}\text { 温革上星始時間 } \\
\end{array}$} & \multirow{2}{*}{ 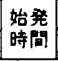 } & $\mathrm{m}: 1.0$ & $\mathrm{~m}: 1,1$ & $\mathrm{~m}: 0.9$ & $\mathrm{~m}: 1.0$ & $m: 1.0$ & $\mathrm{~m}: 1.0$ & $\mathrm{~m}: 1.0$ \\
\hline & & Cv:21.1 & Cv: 30.5 & Cv:21.6 & Cv: 16.2 & Cv:9.0 & Cv: 12.4 & Cv:23.8 \\
\hline
\end{tabular}

図 19 最大温度到達時間と始発時間の関係（混和材）

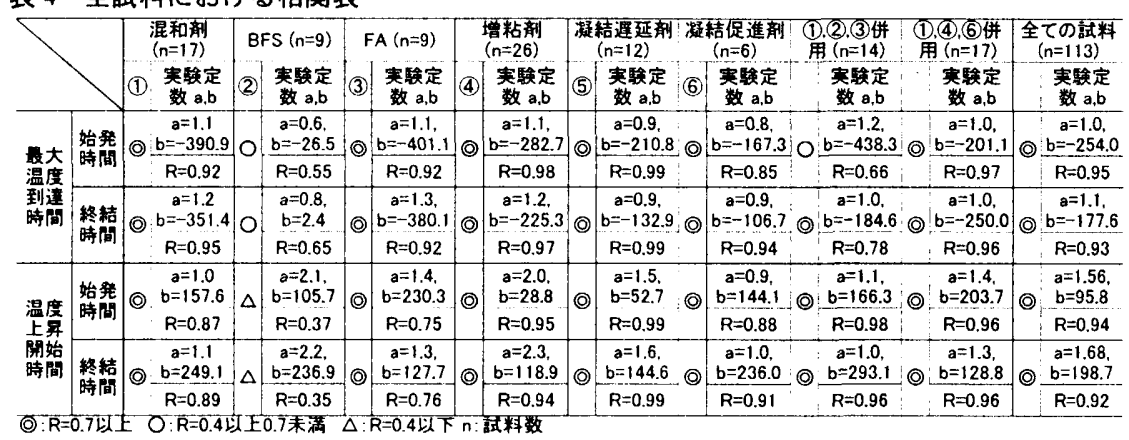

表 5 推定時間と始発時間の平均値および変動係数

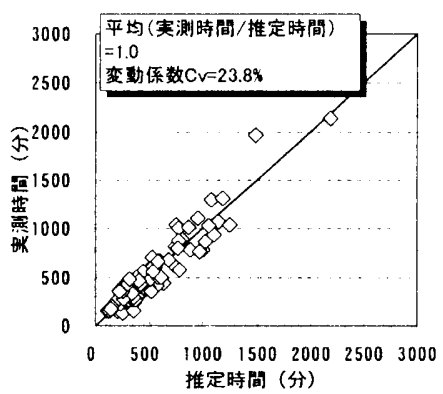

図 20 温度上昇開始時間におけ る推定時間と始発時間の比較

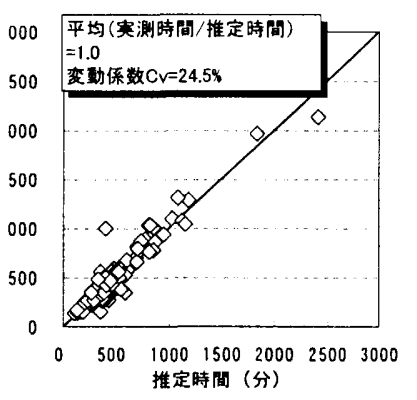

図 21 最大温度到達時間におけ る推定時間と始発時間の比較

\section{[参考文献]}

1）滛崎侣，松藤泰典ほか 3 名：超音波の波動伀達係数によるコンクリートの 凝絬硬化性状詊価に関する基礎的研究（その1，その2），日本建築学会大会学 術講演梗概集, pp.1201〜1204, 1993.9

2）川野辽正徳ほか 5 名：吴りコンクリートを再利用したポンプ理送用先送り モルタルに関する矢験的研究，日本建築学会技術報告集，第 9 号, pp.1-6, 1999.12 3）!川勉ほか 4 名：堌粘剂（セルロースエーテル）がセメント硬化体の凝絬

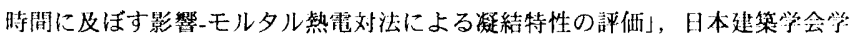
術講演梗概集 A-1, pp.477 478, 2002.8

4）山川勉ほか 5 名：セメント硬化体のモル夕ル熱電対による凝絬時間の評响 (その 1, その 2), 日本建築学会大会学術講演梗概集 A-1, pp.593 596, 2003.8 5）山川勉ほか 5 名：セメント硬化体のモルタル熱電対による凝結時間の評缏 (その 3, その 4), 日本建築学:会大会学術講演梗概集 A-1, pp.265 268, 2004.8 6）稻暏宣生ほか 2 名：統計学入門 裳華原 1992.11 